\title{
Why is Coccinella septempunctata so successful? (A point-of-view)
}

\author{
Ivo HODEK $^{1}$ and J.P. MICHAUD ${ }^{2}$ \\ ${ }^{1}$ Institute of Entomology, Biological Centre, Czech Academy of Sciences, České Budějovice, 37005 Czech Republic; \\ e-mail: hodek@entu.cas.cz \\ ${ }^{2}$ Department of Entomology, Agricultural Research Center-Hays, Kansas State University, Hays, Kansas, 67601 USA; \\ e-mail: jpmi@ksu.edu
}

\begin{abstract}
Key words. Coccinellidae, ladybirds, Coccinella septempunctata, Harmonia axyridis, Adalia bipunctata, Coleomegilla maculata,
\end{abstract} biological control, diapause, diet, foraging, intraguild predation, migration, oviposition, polyphenism, reproduction, voltinism

\begin{abstract}
Factors were examined that could be responsible for the predominance of Coccinella septempunctata (C7) in most habitats of the Palaearctic and for its successful invasion of the Nearctic Region. C7 is euryphagous, but less polyphagous than Harmonia axyridis or Coleomegilla maculata in that it cannot develop or reproduce on non-aphid food. The intraguild status of C7 is intermediate. Although adult size is large, preimaginal stages are palatable to those of H. axyridis and Adalia bipunctata, whereas it is not an intraguild predator of these species. Although these traits appear to be neutral or negative, many aspects of population plasticity are advantageous for $\mathrm{C} 7$, often acting in concert with a bet-hedging strategy. Given its high mobility and eurytopy, the inhibition of oviposition in the presence of conspecific larval trails represents an adaptive advantage that favors increased egg dispersal and lowers the risk of offspring mortality due to cannibalism. The ability to temporarily suspend oviposition, combined with heterogenous voltinism and diapause tendencies, enable a portion of $\mathrm{C} 7$ populations to feed and reproduce on unpredictably occurring aphid populations. An absence of reproductive diapause in males and pre-hibernation mating are other significant adaptations, along with the tendency to produce offspring in excess of the carrying capacity of local food resources. We suggest that one explanation for the broad geographic success of C7 resides in an ecological plasticity that is based on both genetic and phenotypic polymorphisms.
\end{abstract}

\section{INTRODUCTION}

Although Coccinella septempunctata (C7) was the most studied coccinellid species in the period 1995-2004 (Sloggett, 2005), various aspects of its ecology and behavior are not yet completely understood. These lacunae in knowledge have fostered contradictory views regarding its associations with aphid prey. However, it has achieved high abundance and a dominant role among Palaearctic coccinellids in particular habitats (e.g. Honěk \& Hodek, 1996; Ricci et al., 2005) and has been implicated in the displacement of native coccinellid species, particularly of Coccinella novemnotata (Wheeler \& Hoebeke, 1995; Snyder \& Evans, 2006; Frank \& McCoy, 2007; Harmon et al., 2007) following its invasion of the Nearctic (Elliott et al., 1996; Reitz \& Trumble, 2002). In general, most introduced species fail to become established (Mack et al., 2000). The successful establishment of C7 across extensive regions of the USA and Canada (e.g. Krafsur et al., 2005) indicates its ecological flexibility, even if its distribution in the western USA was enhanced by additional releases following the invasion of Diuraphis noxia (Louda et al., 2003). The invasive success of $\mathrm{C} 7$ in North America contrasts with the inability of Adalia bipunctata to expand its distribution in Japan after its establishment near Osaka in 1994 (Sakuratani et al., 2000; Kajita et al., 2006).

While some authors prefer to treat aphidophagous coccinellids as a rather uniform group ecologically (Dixon, 2000), we emphasize the need to study traits specific to individual species. Aphidophagous coccinellids differ in prey and habitat specificity, voltinism tendencies, migratory behavior, and life histories (Hodek \& Honěk, 1996a). Individual species vary considerably in their impact on aphid population dynamics. Recent studies have suggested that conservation biological control strategies should focus more on key predator species than on overall abundance of predators. For example, Coccinella species, including C7, were recorded as key aphid predators in a study in potato fields in the state of Washington, USA (Straub \& Snyder, 2006). A survey of characteristics of dominant ladybird species thus appears badly needed. The ecology of Harmonia axyridis has already been reviewed (Koch, 2003; Lucas et al., 2007) and it seems appropriate to examine $\mathrm{C} 7$ as another dominant species.

Observations of the eurytopy and euryphagy of C7 (Hodek \& Honěk, 1996a) suggest it is a generalist with a broadly flexible life history. We suggest that these characteristics provide substantial advantages over more specialized species in the exploitation of diverse and inherently ephemeral prey. This essay reviews those characteristics of $\mathrm{C} 7$ that we suspect contribute to its "achievements". A broad comparison of traits with other aphidophagous coccinellids is not feasible here due to space limitations and the lack of detailed field studies on most other ladybirds (Sloggett, 2005). Thus, it is possible that some traits, attributed here as specific to $\mathrm{C} 7$, are not exclusive to this species; future studies might reveal them also in other ladybirds. For example, the plasticity of reproductive activity observed in $\mathrm{C} 7$ has recently been 
reported in another common species, Hippodamia convergens (Michaud \& Qureshi, 2006). Here we focus on comparisons of $\mathrm{C} 7$ with $A$. bipunctata, $H$. axyridis and Coleomegilla maculata.

In contrast to many coccinellids that are less abundant and more specialized, C7 shows traits consistent with a "risk-prone" existence (Hodek, 1966). More often then other species, C7 shows a tendency to produce offspring in excess of the carrying capacity of the local food resources. Due to the ephemerality of aphid prey and general environmental uncertainties, a proportion of progeny (sometimes rather large) may be placed at high risk of mortality. For example, it has regularly been observed in summer that millions of hungry C7 swarm, eventually to fall into seas or lakes and become washed ashore (Hodek, 1960, 1996a; Hagen, 1962; Klausnitzer, 1989; Majerus, 1994; Turnock \& Wise, 2004). However, the high fecundity of $\mathrm{C} 7$ and bet-hedging oviposition tactics lead to a wide distribution of eggs in both time and space. Thus many oviposition decisions that appear maladaptive for offspring in specific contexts may nevertheless yield the highest maternal fitness when averaged over time. Similarly, population level phenomena that appear strongly maladaptive when viewed in isolation may yield benefits under different ecological conditions.

In the last part of this essay, we try to resolve some perceived misunderstandings regarding the 'usefulness' of aphidophagous coccinellids by stressing the principal difference between the classical approach to biological control and other forms, particularly conservation biological control.

\section{FOOD SPECIFICITY}

$\mathrm{C} 7$ is not as widely polyphagous as other species, e.g., Coleomegilla maculata or Harmonia axyridis, that can develop and/or reproduce successfully when fed nonaphid food such as pollen, moth eggs or drone bee powder (Smith, 1960; Hodek et al., 1978; Niijima et al., 1986). The list of essential prey recorded to date for C7, (i.e. those supporting both development and reproduction), is nevertheless extensive, comprising at least 24 aphid species, if we include species of relatively low suitability such as Aphis fabae and Megoura viciae (Hodek, 1996b, p. 171). However, several aphids have been reported as deleterious to C7, e.g. Aphis sambuci (Hodek, 1956) and Macrosiphum albifrons (Gruppe \& Roemer, 1988). More examples can be found in Hodek (1996b, pp. 159-165).

While C7 can be considered a somewhat narrow generalist with respect to essential prey species, it is broadly euryphagous in its alternative or supplementary food sources and this can provide important advantages during periods when mere survival is more important than successful reproduction. Soon after emergence from dormancy shelters, the overwintered beetles feed on plant nectaries, e.g. of Prunus spinosa, and in the prediapause period, when aphids are scarce, on pollen of Compositae and Umbelliferae and on fungal spores. These foods are used to accumulate energy reserves in fat bodies that enable adults to survive long periods without access to essential prey (Ricci et al., 2005).

It can be concluded that $\mathrm{C} 7$ is a euryphagous coccinellid capable of exploiting many aphid species and supplementary food sources over the growing season in diverse, although primarily herbaceous, habitats. Nevertheless, C7 appears to be less polyphagous than $H$. axyridis and $A$. bipunctata, species than can utilize far greater numbers of aphid species as essential prey (Koch, 2003; Hodek 1996b, p. 170).

\section{FORAGING BEHAVIOR}

\subsection{Habitat specificity}

Although A. bipunctata may be more polyphagous than C7 (Hodek, 1956; Blackman, 1967a, b), it is a narrower habitat generalist, occurring preferentially in arboreal habitats (Mills, 1979; Honěk \& Hodek, 1996; Iperti, 1999, p. 335; Sakuratani et al., 2000; Sato et al., 2005; Eigenbrode et al., 2008). This stenotopy is associated with a morphological adaptation, a well developed anal disc in A. bipunctata larvae that is useful for adhering to plant surfaces. This is particularly important for larvae that develop on a tree or shrub, since these host plants are more difficult for dislodged larvae to regain compared to herbaceous vegetation. When comparing the attachment forces of five species of coccinellid larvae to pea plants, Pisum sativum, with crystalline epicuticular waxes Eigenbrode et al. (2008) recorded very high values for $A$. bipunctata larvae. On clean glass the attachment force of A. bipunctata was much greater $(6.3 \mathrm{mN})$ than that of $\mathrm{C} 7$, C. transversoguttata or $H$. convergens $(2.6-2.8 \mathrm{mN})$. Only $H$. axyridis, another arboreal species, generated greater values $(11.4 \mathrm{mN})$. The stenotopy of $A$. bipunctata is also associated with reduced mobility of adults; they disperse less often over the steppe-like central European landscape than do the more eurytopic C7 adults (Honěk \& Hodek, 1996, pp. 128-144).

In contrast to $A$. bipunctata, $\mathrm{C} 7$ is a typical inhabitant of grasslands and fields (Osawa, 2000; Honěk \& Martinková, 2005), although it has also been observed to breed in other habitats that include apple orchards (Honěk \& Hodek 1996, p. 130), shrubs (Mills, 1981; Holloway et al., 1991), and even Scots pine (Pinus sylvestris) (Majerus, 1994). Such eurytopy was observed also after the invasion of $\mathrm{C} 7$ to the Nearctic region, when it was found on poplar, Populus spp., in addition to field crops and weeds (Maredia et al., 1992; Brown \& Miller, 1998). Until recently, the rural landscape of central Europe was quite hospitable for $\mathrm{C} 7$, although this situation could be changing given the decline in cereal production in favor of cruciferous crops such as rape (Brassica napus) (Honěk \& Martinková, 2005) that host primarily Brevicoryne brassicae, a rather unsuitable prey for ladybirds because of its waxy secretions (Hodek, 1996b).

The complexity of cues utilized by adults in orienting to specific habitats is not yet well understood, but may involve semiochemicals of both plant and insect origin. For example, Zhu \& Park (2005) showed that adult C7 were strongly attracted to traps baited with methyl salicy- 
late, a volatile released by soybean (Glycine sp.) plants infested with Aphis glycines, whereas $H$. axyridis adults did not respond, despite the fact they are also an abundant predator of this aphid in the soybean agroecosystem (Fox et al., 2004). These results are indicative that different host plant-aphid combinations can be differentially attractive to various coccinellid species. In other cases, particular plants may be attractive to many coccinellid species because they supply valuable resources in the absence of prey. Examples include the attraction of $C$. maculata to maize (Zea mays) in the absence of aphid infestation, and the attraction of numerous coccinellid species to the extra-floral nectaries of sunflower, Helianthus annuus (Michaud \& Qureshi, 2005). When the density of aphids is low in alfalfa (Medicago sativa), C7 adults aggregate in local concentrations of the alfalfa weevil (Hypera postica), although weevil larvae serve only as supplemental food (Evans \& Toller, 2007). Two native Hippodamia spp. did not respond the same way to this alternative prey, leading the authors to suggest that this difference may account in part for the displacement of native ladybirds from alfalfa by $\mathrm{C} 7$.

Majerus (1994) considered both A. bipunctata and C7 to behave as generalists in England, and reported them as abundant in a wide range of herbaceous and arboreal habitats, mentioning umbellifers, nettles and grain crops. In Belgium, Hemptinne (1989) collected A. bipunctata on apple trees, nettles and wheat (Triticum sp.). The notable differences between records from England (and Belgium) and most other data from central, southern and eastern Europe (Honěk \& Hodek, 1996) are still lacking explanation. The generally higher humidity in England might favor the retention of $A$. bipunctata in non-arboreal habitats there, but comparative studies on humidity relations of these two species are lacking. Alternatively, genetic divergence of geographically separated populations may sometimes lead to novel habitat associations.

\subsection{Seasonal availability of aphids}

Many aphids produce their peak populations in spring. In central Europe, cereal aphids, and $A$. fabae on sugar beet (Beta vulgaris), usually increase in numbers exponentially in late May and June. However, many aphid species can occur also in summer and early autumn, albeit in low abundance. Examples include Myzus persicae in mid August in Germany (Unger \& Mueller, 1954), Microlophium carnosum in September in England (Perrin, 1976), Euceraphis punctipennis in mid September in England (Wratten, 1974), Eucallipterus tiliae in some years in late August and early September in UK (Dixon, 1971), and various aphids on Cirsium, Rumex and Urtica spp. weeds in July and August in northern Italy (Burgio et al., 2006). These authors also list weeds that serve as late season refuge hosts for aphids in other habitats after arable crops are harvested. On some crops, such as beans (Vicia faba), hops (Humulus lupulus) and alfalfa (M. sativa), aphids are present in late summer and early autumn in central Europe. The same is true for aphids on weeds (e.g. Aphis cirsii, Uromelan aeneus, Cavariella spp.). In France, in Low Normandy, many species occur throughout winter (Remaudière et al., 1980). Similarly, Schizaphis graminum can survive in active stages under snow cover in Oklahoma (K. Giles, pers. commun.). In individual years, the abundance of aphids depends on environmental factors, particularly precipitation and temperature, and is thus often unpredictable. The notorious ephemerality of aphid prey may have led to the evolution of plastic and variable reproductive behavior in populations of C7 and other aphidophagous coccinellids.

\subsection{Relation to aphid parasitoids}

Aphid parasitoids have been shown to avoid leaves previously visited by adult coccinellids. The avoidance response of two Aphidius spp. to C7 trails was stronger than to those of $A$. bipunctata. It was found that the hydrocarbons n-pentacosane and n-heptacosane occur in significantly greater amounts in C7 trails compared to $A$. bipunctata (Nakashima et al., 2006). This response may preserve food resources for both $\mathrm{C} 7$ adults and their offspring and disperse aphid parasitism more widely among aphid patches. Although several authors have pointed out the potential negative impact of coccinellid predation on aphid parasitoids within their hosts (Ferguson \& Stiling, 1996; Colfer \& Rosenheim, 2001), little attention has been given to the consequences for coccinellids when they prey on parasitized aphids.

\subsection{Movement among habitats}

Due to their eurytopy and high vagility, C7 adults range widely over large expanses of landscape and feed and reproduce in many habitats. Their offspring are thus also widely dispersed, and the deterrent effect of larval tracks on oviposition (see 4.1) prevents the clumping of preimaginal stages in the richest patches of prey, reducing intraspecific competition. The vagility of $\mathrm{C} 7$ was noted by Elliott et al. (1998) who observed that the more vagile $\mathrm{C} 7$ and $H$. convergens were more affected by broader scale variation in landscape structure compared to the less vagile species Coleomegilla maculata and Hippodamia parenthesis. (See also Brewer \& Elliott, 2004.) Evans (2004) reported that in Utah, USA, alfalfa fields, C7 females are more attracted to low density Acyrthosiphon pisum populations than are native ladybird species. Snyder et al. (2004a) suggested that the early arrival of C7 in developing aphid colonies, and their earlier oviposition there, gave larvae a size advantage over the laterdeveloping offspring of native species.

Use of alternative habitats by $\mathrm{C} 7$ was followed in detail over two seasons in Michigan, USA by Maredia et al. (1992). A diverse agroecosystem composed of a mosaic of habitats supported C7 populations from late April till the end of August feeding on various aphid species hosted by annual and perennial crops (wheat, maize, soybean and alfalfa), poplar and weeds. In northern Italy, Burgio et al. (2006) observed seasonal movements of Hippodamia variegata, C7 and Propylea quatuordecimpunctata among arable crops, fallow and vegetable crops and weedy field margins. 
A heterogeneous landscape presents a mosaic of patches within which $\mathrm{C} 7$ adults can select those that happen to be suitable at a given time. Evidence is still lacking with respect to the sensory cues employed by $\mathrm{C} 7$ adults to locate profitable patches, although there are records of olfactory responses of adult coccinellids to aphids at short distances (Sengonca \& Liu, 1994; Mondor \& Roitberg, 2000; Acar et al., 2001). Thus, many have suggested (Ives et al., 1993; Osawa, 2000; van der Werf et al., 2000) that flying adults arrive in patches at random and then make decisions to stay or leave based on the presence or abundance of prey as well as signals left by conspecific larvae. It has been estimated (Frazer, 1988) that as many as $50 \%$ of ladybirds emigrate from a patch every day only to be replaced by immigrants. Thus the abundance of adult coccinellids in a patch reflects the net balance between rates of immigration and emigration. Empirical evidence indicates that there is greater emigration from patches of lower quality than from patches of higher quality (Kareiva, 1990; Osawa, 2000). Notably, a recent study showed that predator emigration from a patch decreased with increasing aphid abundance (Cardinale et al., 2006). Further detailed studies on the emigration behaviour of ladybirds are warranted and should focus on the effects of different levels of adult satiation, as suggested by Evans (2003).

Kindlmann \& Dixon (1993) introduced the concept of an "oviposition window" - a critical period of time in the development of an aphid colony when coccinellid eggs should be laid in order to ensure sufficient food to support completed larval development. However, suitable sites for C7 oviposition do not appear simultaneously on different species of plants or aphids, or even on the same plants under different environmental conditions, and thus may appear and disappear almost continuously when a large, heterogeneous landscape is considered. This scenario of continuous movement (accompanied by feeding and oviposition) among patches in an open system of heterogenous habitats does not favor, in our opinion, any mechanism that would limit $\mathrm{C} 7$ oviposition to a narrow time window. We suggest that this concept is valid when isolated aphid patches are considered, but has few population consequences for highly mobile ladybirds. In reality, there may be other aphid patches in the landscape with different phenological windows that are within the reach of ladybird females. The "window" assumption might be more applicable to strictly stenotopic or less mobile species. When one patch becomes unfavorable for oviposition, C7 females can disperse to other patches where the "window is still open" and repeat this behavior many times throughout the season.

\subsection{Fall migration}

In late autumn, when most aphids have disappeared from crops and weeds and migrated to their primary woody hosts, the aphid-coccinellid dynamic ends. In central Europe, C7 starts aggregating in hibernation sites in August, while Ceratomegilla (= Semiadalia) undecimnotata arrives there in early/mid July (Hodek, 1960, 1962, 1996b; Honěk, 1989; Nedvěd et al., 2001). As adult lady- birds gradually migrate to their hibernation sites, most feed on alternative food sources (pollen, fungal spores) and also on the remnants of aphid populations that sometimes exploit senescent plants (Ricci et al., 2005).

\section{OVIPOSITION BEHAVIOR}

C7 females oviposit in patches where they find and consume sufficient quantities of essential prey. Nevertheless, ovipositing females possess an inherent dispersal tendency even in the presence of suitable prey and in the absence of conspecific or intraguild competitors in the patch (Frazer \& Raworth, 1985; Hodek \& Honěk, 1996b; Evans, 2003). This tendency was demonstrated in experiments where aphids were freshly introduced onto plants and the ladybirds directly observed (Ives et al., 1993). Secondly, residues of C7 larvae deposited by the anal disk are deterrent to ovipositing conspecific females as they are indicative of a high risk of egg cannibalism in the patch.

\subsection{Oviposition deterrence}

The observation that $A$. bipunctata females did not oviposit in patches where conspecific larvae were encountered led at first to an erroneous assumption that physical contact of the female with the larva is needed to produce the inhibition (Hemptinne et al., 1992). Subsequent research has revealed that the tracks of crawling aphidophagous larvae deter oviposition by females of the same species (Růžička, 1994, 1997; Doumbia et al., 1998), and sometimes those of other species as well (Michaud \& Jyoti, 2007).

Deterrence based on semiochemicals is obviously more efficient than deterrence in response to physical contact. Although robust comparisons are not yet possible, the deterrency of conspecific larval tracks seems strongest in smaller coccinellid species (Růžička, 2001). Although operational in $\mathrm{C} 7$ this deterrent mechanism is weaker than in other species, e.g. Ceratomegilla (Semiadalia) undecimnotata (Růžička, 2001). These semiochemicals in the residues left by coccinellid and chrysopid larvae vary among species in their environmental persistence. Whereas the residues of Cycloneda limbifer remain deterrent even after 30 days, those of $C$. undecimnotata last five days, and those of C7 only one day (Růžička, 2002). In experiments with $A$. bipunctata the deterrence lasted 10 days (Hemptinne et al., 2001). C7 females are also remarkable in their relatively low sensitivity to larval tracks of heterospecific larvae (Růžička, 2001). This relatively low sensitivity to signals deterrent to other species may indicate that $\mathrm{C} 7$ is less sensitive to the risk of intraguild predation compared to other coccinellids.

Despite a low sensitivity to oviposition-deterring semiochemicals, C7 females still recognize them and may seek other plants or habitats. The distribution of offspring among numerous prey patches may reduce intraspecific competition and cannibalism, and spread risks of offspring mortality among multiple patches. 


\subsection{Oocyte resorption}

Female C7 may temporarily discontinue maturation of oocytes and cease oviposition when suitable prey are in short supply, and subsequently resume reproduction when conditions improve (Zaslavsky \& Vaghina, 1996). This reproductive strategy occurs in other generalist coccinellid species such as $H$. axyridis (Osawa, 2005), $C$. (S.) undecimnotata (Katsoyannos et al., 2005) and H. convergens (Michaud \& Qureshi, 2006) and may consist either of a simple delay in oocyte maturation, or involve the active resorption of eggs. Sloggett (2005) pointed out that oosorption was not studied in coccinellids until very recently and considered it a characteristic of generalist species that may be absent in more specialised ones, such as Adalia decempunctata.

\section{DIAPAUSE AND VOLTINISM}

\subsection{Voltinism}

Diapause in C7 has been studied mostly in regions with temperate climates where populations show heterogeneous voltinism tendencies. Typically, a greater part of a population tends toward an obligatory univoltine cycle, while a smaller proportion (differing across geographical regions and individual years; $13-20 \%$ in a study executed in central Europe) is facultatively polyvoltine (Hodek, 1962, 1996b). After establishment of C7 in the Nearctic region, similar population variation in diapause tendency was reported from New Jersey, USA (Angalet et al., 1979) and New York (Obrycki \& Tauber, 1981). The great plasticity of $\mathrm{C} 7$ is evident also in two geographical populations of the subspecies $C$. septempunctata brucki in Japan. In Hokkaido in the north, hibernal diapause is induced by short days, whereas the population in central Honshu enters estivation diapause under long days and hibernates in quiescence (Sakurai et al., 1981; Okuda \& Hodek, 1983; Hodek et al., 1984; Ohashi et al., 2003). Another case of plasticity in C. s. brucki has been reported recently: some adults may produce an additional generation by taking advantage of artificial substrates warmed by direct exposure to sunlight (metal cans, paper, pieces of wood) at ambient temperatures otherwise too low to permit the development of eggs and pupae (Ohashi et al., 2005).

\subsection{Diapause induction}

Hagen (1962) used the term "semi-estivo-hibernation" to describe the early onset of diapause in C7. In central Europe, the first individuals of the univoltine fraction of the population enter hibernation sites in early August, while those of the multivoltine fraction in the same region continue to feed through September and early October on aphid-infested weeds, and may possess eggs or vitellinized oocytes in the ovaries (Hodek, 1962, 1996b). In central Italy, pollen and spores of fungi were found in the guts of pre-diapause $\mathrm{C} 7$ adults in addition to aphids (Ricci et al., 2005). Variable voltinism and plastic reproductive behaviour generate overlapping generations and enable portions of the $\mathrm{C} 7$ populations to take advantage of various supplemental food resources that become available late in the season to augment their nutritional reserves for hibernation.

\subsection{Gonads}

Whereas females typically arrive at hibernation shelters with undeveloped ovaries, the testicular follicles of males remain active during the early warm period of dormancy, until the temperature falls below about $12^{\circ} \mathrm{C}$ (Hodek \& Landa, 1971), and at least some males are able to mate. About $50 \%$ of $\mathrm{C} 7$ females dispose of the sperm in their spermathecae in September, whereas females of Coccinella quinquepunctata and Ceratomegilla (= Semiadalia) undecimnotata are not fertilized until the spring (Hodek \& Ceryngier, 2000; Ceryngier et al., 2004). Sperm disposal by females increases intrasexual competition among males and should select for repeated matings in prehibernation aggregations.

\subsection{Hibernation shelters}

C7 populations vary in dormancy behavior and display a broad eurytopy with respect to hibernation habitats and microhabitats (Hodek, 1996a, p. 274). The adults overwinter most often in the litter, in grass tussocks, near the base of plants, or under small stones. They prefer to overwinter on a prominent landscape elevation, such as a knoll or hill, especially if these are near the breeding habitat; overwintering $\mathrm{C} 7$ were found in the mountains of France, Czech Republic and Poland at about $1500 \mathrm{~m}$ elevation (Hodek et al., 1977; Honěk, 1989; Ceryngier, 2000). If the landscape is not hilly, dormancy sites are usually selected along forest edges, in windbreaks, or in undulating portions of the terrain. The diversity of potentially suitable overwintering habitats for $\mathrm{C} 7$ further contributes to its broad eurytopy in both breeding and dormancy.

Population-level plasticity in life-history traits was documented in four C7 populations collected from France, Ukraine and the USA (Iowa, Delaware), by Phoofolo \& Obrycki (1995, 2000), who corroborated findings from central Europe in the 1960's and 1970's (Hodek, 1996b). Phoofolo \& Obrycki (1995, 2000) considered C7's phenotypic variation in life-history traits as "evidence of either genetically based bet-hedging or phenotypic plasticity, or a combination of these strategies" and implied that these characteristics are among those responsible for the "success" of C7 in non-native regions.

\subsection{Termination of hibernation}

Diapause ends about halfway through the dormancy period and, by spring time, adults are simply in thermal quiescence. Adults emerge from hibernation in response to rising temperatures. Depending on thermal gradients within hibernation shelters (typically due to varying degrees of insolation), more than one month may elapse between departures of the first and last individuals from a particular site (Hodek, 1960). Variance in age at onset of reproduction was considered by Lewontin (1965) to be an important characteristic associated with colonizing ability, and Michaud \& Qureshi (2006) concluded it was a key life history character contributing to the dominance of $H$. convergens in the High Plains region of the central 
USA, a comparatively inhospitable habitat for aphidophagous coccinellids. This variation comprises a form of insurance policy for the population whenever it faces uncertainty in the timing of aphid abundance. Various dormancy phenomena thus contribute to the overall plasticity of $\mathrm{C} 7$ populations, particularly the variation among individuals in voltinism, diapause and timing of emergence from hibernation.

\section{INTRAGUILD RELATIONS}

Intraguild predation (IGP) has recently become a popular topic in biological control and conflicting views have been published. Some authors suggest that the net effect of IGP is often disruptive to an aphidophagous guild, e.g. ladybirds disturb foraging parasitoid adults and eat parasitized aphids (Dixon, 2000). Ferguson \& Stiling (1996) concluded from a field cage study that the effects of IGP were non-additive; parasitoids reduced aphid populations (Uroleucon sp.) more effectively in the absence of coccinellids. In contrast, recent glasshouse experiments indicated that $H$. axyridis complemented biocontrol of Macrosiphum euphorbiae by the parasitoid Aphelinus asychis (Snyder et al., 2004b) despite consumption of mummies. Others have concluded that even high rates of IGP by coccinellids on parasitoids can have little effect on the outcome of biological control under open field conditions (Colfer \& Rosenheim, 2001). Kindlmann \& Houdková (2006) concluded from other outdoor experiments that IGP is often unimportant in the field and warn that the results of laboratory IGP experiments should be interpreted with caution. Yano's (2006) review suggests that IGP may be even less important to biological control in protected culture than in the field.

Here we address only one aspect of IGP, interactions among aphidophagous ladybird species. The larvae of $\mathrm{C} 7$ lack morphological features such as spines or waxy coverings that may defend some ladybird species from predation (Volkl \& Vohland, 1996; Agarwala \& Yasuda, 2001; Michaud \& Grant, 2003). It has been suggested that the most efficient way for defenceless young larvae to escape the attacks of older larvae or those of more aggressive species (e.g. H. axyridis) is by dropping from plants (Sato et al., 2003, 2005), much as some aphids escape their parasitoids (Chau \& Mackauer, 1997). In experiments, where larvae were deprived of this escape route, the results of intraguild interactions are typically biased in favour of the more aggressive competitor (Michaud \& Grant, 2003).

Under conditions of low prey availability in small cages, larvae of $\mathrm{C} 7$ were favored in competitive interactions with larvae of C. maculata (Obrycki et al., 1998). The authors suggested that the effect was due to the greater size of C7 larvae compared to similar-aged $C$. maculata larvae.

When IG interactions were examined between two native North American species (H. convergens and $C$. transversoguttata) and two introduced species (C7 and $H$. axyridis) in microhabitats consisting of pea (Pisum sp.) plants and aphids, both introduced species were superior to the natives (Snyder et al., 2004a). IG predation was frequently observed between the two introduced species, but neither had a consistent advantage over the other. Nevertheless, $H$. axyridis appeared more successful in preying on the two native species than did $\mathrm{C} 7$ and various mechanisms have been proposed to explain why $H$. $a x y$ ridis larvae may be especially effective IG predators. These include the presence of short spines on the dorsal surface (Michaud, 2002), adhesive tarsi and chemical defence (S. Eigenbrode, W. Snyder and G. Clevenger, pers. commun.), and a generally high level of aggression that yields 'first strike' advantages (Michaud \& Grant, 2003). Cardinale et al. (2006) reported dominance of C7 in behavioral interactions between adults, not only with C. maculata, but also with $H$. axyridis. In contrast, the IG superiority of $H$. axyridis larvae over C7 larvae was revealed indirectly in a study focused on A. bipunctata in Japan (Kajita et al., 2006) in which the survival of $A$. bipunctata larvae was reduced in the presence of $H$. axyridis larvae, but not those of $\mathrm{C} 7$.

Harmonia axyridis began invading the United States in 1988 (Chapin \& Brou, 1991) and, by the late 1990s, had successfully invaded the citrus groves in Florida where it displaced Cycloneda sanguinea as the dominant coccinellid predator of Toxoptera citricida (Michaud, 2002). In a similar time frame, $H$. axyridis invaded the apple orchards of West Virginia where it quickly became the dominant coccinellid predator of Aphis spiraecola, replacing the formerly dominant $\mathrm{C} 7$ (Brown, 2003). In field crops of the High Plains region of the central United States, however, $H$. axyridis has not become a prominent coccinellid, although it has been present there for more than a decade (Michaud \& Qureshi, 2006). The difference may be due to either the arid climate or a certain preference of $H$. axyridis for arboreal habitats (Lucas et al., 1997), although its willingness to enter fields of corn (Zea mays) (Lundgren et al., 2004; Galvan et al., 2005) and soybean (Glycine sp.) (Fox et al., 2004; Mignault et al., 2006) appears rather anomalous in this perspective. A recent prediction (van Rijn et al., 2006) is that $H$. axyridis will not replace the less aggressive $\mathrm{C} 7$ in certain habitats because of its relatively high level of cannibalism. Because of its relatively large size compared to most ladybirds native to Europe and the Nearctic region, C7 might be expected to be a formidable predator in IG interactions. Experiments showed, however, that feeding on IG competitors, such as larvae of $H$. axyridis, can cause high mortality in C7 larvae, whereas the reverse is not true (Yasuda \& Ohnuma, 1999). Also, feeding on eggs of A. bipunctata is detrimental for C7 development (Agarwala \& Dixon, 1992) and fourth instar larvae are reluctant to do so (Hemptinne et al., 2000).

Thus, in spite of its size, C7 appears to be a less formidable IG predator than $H$. axyridis. It will be informative to observe the outcome of current competitions between $\mathrm{C} 7$ and $H$. axyridis in habitats of the Nearctic region, and later in the Palaearctic region. The current era of IG superiority of $\mathrm{C} 7$ in many habitats may be short-lived in the face of range expansion by the more competitive $H$. axy- 
ridis. Those habitats in which $\mathrm{C} 7$ resists displacement by $H$. axyridis may provide important clues to environmental factors that are ecologically favorable to C7.

\section{SUCCESSFUL - BUT NOT USEFUL?}

The main focus of this essay is not applied biological control, but our discussion of $\mathrm{C} 7$ ecology is relevant to the debate about the potential impact of aphidophagous ladybirds on aphid population dynamics. Aphids often achieve elevated and damaging populations on crops despite the presence of numerous coccinellids. However, we should not underestimate the biological control potential of aphidophagous insects, including coccinellids, simply because they do not always regulate populations of aphids to our satisfaction. It is well recognized that coccinellids are important agents of natural (spontaneous) biological control and it would be unwise to neglect their potential (e.g. Smith \& Hagen, 1966; Rice \& Wilde, 1988; Obrycki \& Kring, 1998; Michaud, 2004; Kriz et al., 2006). Their potential has often become evident when predators were eliminated by pesticides, or when a cold spring favored the reproduction of aphids but inhibited the activity of coccinellids. It should also be recognized that large and damaging aphid infestations are rare in natural ecosystems and mostly confined to agricultural crops where they may arise largely as a function of agricultural practices that favor their population increase over that of their natural enemies.

Coccinellids have been successfully used as components of biological control within a framework of integrated pest management and in augmentative programs as early as the 1950 s, e.g. against alfalfa aphids (Stern et al., 1959). Conservation approaches, such as intercropping (Fye \& Carranza, 1972; Patt et al., 1997) and other modifications of agriculture practices and landscape use patterns, are promising ways to encourage native coccinellids to enter managed ecosystems and increase their impact on aphid populations (Hodek \& Honěk, 1996b, pp. 370-389; Obrycki \& Kring, 1998; Landis et al., 2000). In this sense, we do not concur with rather pessimist views (e.g. Dixon, 2000, p. 217) that assume negligible impact is inevitable. We agree with Hirose (2006), who recommends a focus on conservation biological control utilizing mobile natural enemies of aphids with high reproductive potential. C7 seems eminently well-suited to comply with this requirement.

Symondson et al. (2002) stated that according to "a review of manipulative field studies, in $\sim 75 \%$ cases generalist predators (single species or species assemblages) significantly reduced pest numbers". Together with a parasitoid and two heteropterans, $\mathrm{C} 7$ and $H$. convergens exerted significant control of Myzus persicae and Brevicoryne brassicae in recent cage experiments that showed the role of biodiversity in aphid suppression on collard (Brassica oleracea) (Snyder et al., 2006). Very recently, C7, $C$. maculata and $H$. axyridis have all been reported as important components of the suite of natural enemies controlling pea aphid populations in Wisconsin (Cardinale et al., 2006). The recent emergence of $H$. axy- ridis as a key predator of Aphis glycines in soybean (Glycine sp.) fields of the American Midwest is another example (Gardiner \& Landis, 2007).

Contrasting views have emerged on the impact of aphidophagous coccinellids on the population dynamics of aphids and their potential role in biological control of aphids for several reasons. First, observations on individual species have sometimes been generalized across all aphidophagous coccinellids. Our emphasis in the present essay is that individual species have very specific ecological traits, despite sharing the common habit of aphidophagy. Furthermore, judgements on the usefulness of aphidophagous ladybirds are often made in reference to biological control in general, without discrimination between its different forms. Results of classical biological control efforts with aphidophagous coccinellids may rightly generate a pessimist view with regard to efficacy, but this view is not necessarily valid for the role of ladybeetles in other types of biocontrol.

When compared with coccidophagous coccinellids, aphidophagous ladybirds are much less suitable for the so called "classical" approach in which, after establishment, the imported natural enemies are expected to regulate/control the target insect without any further "assistance" or continuing human inputs, i.e., automatically. This occurred when Rodolia cardinalis was introduced to California against the coccid Icerya purchasi inadvertently introduced earlier (De Bach, 1964). Such a success was possible because "the rate of increase ratio between the predator and prey was in favor of the coccinellid" (Hodek, 1973, p. 215; Hodek \& Honěk, 1996b, p. 352). A similar explanation was given by Hagen (1974) and can be simplified by saying that the success of an introduced natural enemy depends mainly on its generation time relative to that of the target pest. The crucial relationship between predator and prey was already understood in a very early analysis of the "Rodolia miracle", when Thorpe (1930, p. 937) explained the success by stressing that Rodolia "has, roughly, three generations to one of its prey". This classic wisdom has recently been revived under the term "generation time ratio" (Kindlmann \& Dixon 1999, Dixon 2000).

In contrast, only one or two generations of aphidophagous coccinellids have to face many annual aphid generations. Because this reversed situation strongly favours the aphids, aphidophagous coccinellids are ill suited for classical biological control through introductions.

Due to recent recognition of many non-target impacts of invasive ladybirds, most government agencies in the USA have stopped introducing and distributing alien coccinellid species (Louda et al., 2003). Thus, the emphasis in biological control has been shifting away from classical biological control and toward conservation and augmentation utilizing native or already established introduced species (Barbosa, 1998; van Lenteren et al., 2006). This emphasis will require more intensive research on intraguild interactions and a concentration on prominent, widely distributed aphidophagous species such as 
C7. Only detailed knowledge of their ecology and ethology will permit rational human interventions to increase coccinellid impact on target aphid species through appropriate management and modification of cultural practices. For example, even the timing and height of mowing, not only of crop fields, but also field margins, may influence coccinellid abundance and efficacy via effects on food availability and dispersal behavior (Boller et al., 2004; Burgio et al., 2006).

\section{CONCLUSIONS}

Factors were examined that could be responsible for the predominance of $\mathrm{C} 7$ in various coccinellid communities of the Palaearctic and for its successful invasion of the Nearctic Region.

Differences in life-history parameters (rate of development, intrinsic rate of increase, etc.) do not indicate any particular advantage for $\mathrm{C} 7$ over other aphidophagous coccinellid species - even some of those recently displaced by $\mathrm{C} 7$ in North America. C7 is a euryphagous ladybird, perhaps even generalist, but it cannot reproduce without suitable aphid prey, which might represent an important disadvantage under marginal conditions. One might expect $\mathrm{C} 7$ to be favoured by its large size in intraguild interactions with many coccinellid species, but this is not always the case. Species such as A. bipunctata and $H$. axyridis may be favoured over $\mathrm{C} 7$ due to their immature stages being unpalatable or otherwise defended.

While the above mentioned attributes appear either neutral or negative with respect to the ecological success of C7, various aspects of population-level plasticity appear advantageous. Oviposition by $\mathrm{C} 7$ females is inhibited in the presence of conspecific larval trails, although less so in comparison with other coccinellid species. In the context of C7's high mobility and eurytopy, the avoidance of such sites can have important adaptive consequences. Egg distribution over greater spatial scales may lower the overall risk of mortality for offspring due to cannibalism and starvation and reduce the population impact of localized events that inflict density-independent mortality. Distribution of offspring in time is facilitated by temporal variation in onset of oviposition. The ability to resorb oocytes under conditions of food limitation conserves reproductive effort until such time as resources are available to support successful development of progeny.

Heterogenous voltinism and diapause enable a portion of $\mathrm{C} 7$ populations to exploit aphids well into late summer and fall. Such life history plasticity may be a key factor in the species' success, particularly in arid regions where midsummer conditions may be too hot or dry for aphid population development, whereas late summers become favorable once again. An absence of reproductive diapause in males, pre-hibernation mating, and the storage of sperm by females through winter months, are other traits consistent with an overall strategy of ecological opportunism.

Although apparently favoured over C7 (and many other coccinellids) in aggressive interactions, $H$. axyridis does not invariably displace $\mathrm{C} 7$ in all habitats and both species still coexist in certain habitats in USA, as in Japan. The continuing intraguild interactions between $\mathrm{C} 7$ and $H$. axyridis in numerous novel habitats are thus worthy of continued observation to determine final outcomes and infer ecological correlates, as both species are strong competitors and highly successful invasive species.

In conclusion, we suggest that the notorious success of C7 in both native and introduced habitats probably arises from its general ecological plasticity that is based on high levels of individual variation within populations and great phenotypic flexibility in the expression of traits by individuals. The characteristics enumerated above, and the tendency of $\mathrm{C} 7$ to reproduce beyond the carrying capacity of habitats, represent effective adaptations to the ephemeral and unpredictable nature of its aphid prey, adaptations that may be more highly evolved in C7 than in many other aphidophagous species.

ACKNOWLEDGMENTS. The authors are thankful to J.C. van Lenteren, Agricultural University, Wageningen, The Netherlands and W.E. Snyder, Washington State University, Pullman, USA for helpful comments to the first draft of this paper and for sharing unpublished texts. The paper is based on studies financed partly by the grant No A6007303 from the Grant Agency of the Academy of Sciences of the Czech Republic .

\section{REFERENCES}

Acar E.B., Medina J.C., Lee M.L. \& Booth G.M. 2001: Olfactory behaviour of convergent lady beetles (Coleoptera: Coccinellidae) to alarm pheromone of green peach aphid (Hemiptera: Aphididae). Can. Entomol. 133: 389-397.

Agarwala B.K. \& Dixon A.F.G. 1992: Laboratory study of cannibalism and interspecific predation in ladybirds. Ecol. Entomol. 17: 303-309.

Agarwala B.K. \& Yasuda H. 2001: Larval interactions in aphidophagous predators: effectiveness of wax cover as defence shield of Scymnus larvae against predation from syrphids. Entomol. Exp. Appl. 100: 101-107.

Angalet G.W., Tropp J.M. \& Eggert A.N. 1979: Coccinella septempunctata in the United States: recolonizations and notes on its ecology. Environ. Entomol. 8: 896-901.

Barbosa P. (ed.) 1998: Conservation Biological Control. Elsevier, London, 396 pp.

Blackman R.L. 1967a: The effects of different aphid foods on Adalia bipunctata L. and Coccinella 7-punctata L. Ann. Appl. Biol. 59: 207-219.

Blackman R.L. 1967b: Selection of aphid prey by Adalia bipunctata L. and Coccinella 7-punctata L. Ann. Appl. Biol. 59: 331-338.

Boller E.F., Hani F. \& Poehling H.M. 2004: Ecological Infrastructures. Ideabook on Functional Biodiversity at the Farm Level. IOBC/WPRS, Lindau, Switzerland, xiv $+212 \mathrm{pp}$.

Brewer M.J. \& ElLIOTt N.C. 2004: Biological control of cereal aphids in North America and mediating effects of host plant and habitat manipulations. Annu. Rev. Entomol. 49: 219-242.

BRown M.W. 2003: Intraguild responses of aphid predators on apple to the invasion of an exotic species, Harmonia axyridis. BioControl 48: 141-153.

Brown M.W. \& Miller S.S. 1998: Coccinellidae in apple orchards of eastern West Virginia and the impact of invasion by Harmonia axyridis. Entomol. News 109: 136-142.

Burgio G., Ferrari R., Boriani L., Pozzati M. \& van Lenteren J. 2006: The role of ecological infrastructures on Coccinellidae (Coleoptera) and other predators in weedy field margins 
within northern Italy agroecosystems. Bull. Insectol. 59: $59-67$.

Colfer R.G. \& Rosenheim J.A. 2001: Predation on immature parasitoids and its impact on aphid suppression. Oecologia 126: 292-304.

Cardinale B.J., Weis J.J., Forbes A.E., Tilmon K.J. \& Ives A.R. 2006: Biodiversity as both a cause and consequence of resource availability: a study of reciprocal causality in a predator-prey system. J. Anim. Ecol. 75: 497-505.

Ceryngier P. 2000: Overwintering of Coccinella septempunctata (Coleoptera: Coccinellidae) at different altitudes in the Krakonosze Mts, SW Poland. Eur. J. Entomol. 97: 323-328.

Ceryngier P., Havelka J. \& Hodek I. 2004: Mating and activity of gonads in pre-dormant and dormant ladybirds (Coleoptera: Coccinellidae). Invert. Reprod. Dev. 45: 127-135.

Chapin J.B. \& Brou V.A. 1991: Harmonia axyridis, the third species of the genus to be found in the U.S. Proc. Entomol. Soc. Wash. 93: 630-635.

Chau A. \& Mackauer M. 1997: Dropping of pea aphids from feeding site: a consequence of parasitism by the wasp Monoctonus paulensis. Entomol. Exp. Appl. 83: 247-252.

De BACH P. (ed.) 1964: Biological Control of Insect Pests and Weeds. Chapman and Hall, London, 844 pp.

Dixon A.F.G. 1971: The role of intra-specific mechanisms and predation in regulating the numbers of the lime aphid, Eucalipterus tiliae. Oecologia 8: 179-193.

Dixon A.F.G. 2000: Insect Predator-Prey Dynamics. Ladybird Beetles and Biological Control. Cambridge Univ. Press, Cambridge, ix $+257 \mathrm{pp}$.

Doumbia M., Hemptinne J.-L. \& Dixon A.F.G. 1998: Assessment of patch quality by ladybirds: role of larval tracks. Oecologia 113: 197-202.

Eigenbrode S.D., Snyder W.E., Clevenger G., Ding H. \& Gorb S.N. 2008: Variable attachment to plant surface waxes by predatory insects. In Gorb S.N. (ed.): Functional Surfaces in Biology. Springer, New York, pp. 1-35.

Elliott N., Kieckhefer R. \& Kauffman W. 1996: Effect of an invading coccinellid on native coccinellids in an agricultural landscape. Oecologia 105: 537-554.

Elliott N.C., Kieckhefer R.W., Lee J.H. \& French B.W. 1998: Influence of within-field and landscape factors on aphid predator populations in wheat. Land. Ecol. 14: 239-252.

Evans E.W. 2003: Searching and reproductive behaviour of female aphidophagous ladybirds (Coleoptera: Coccinellidae): a review. Eur. J. Entomol. 100: 1-10.

Evans E.W. 2004: Habitat displacement of North American ladybirds by an introduced species. Ecology 85: 637-647.

Evans E.W. \& Toller T.R. 2007: Aggregation of polyphagous predators in response to multiple prey: ladybirds (Coleoptera: Coccinellidae) foraging on alfalfa. Popul. Ecol. 49: 29-36.

Ferguson K.I. \& StiLing P. 1996: Non-additive effects of multiple natural enemies on aphid populations. Oecologia 108: $375-379$

Fox T.B., Landis D.A., Cardoso F.F. \& Difonzo C.D. 2004 Predators suppress Aphis glycines Matsumura population growth in soybean. Environ. Entomol. 33: 608-618.

Frank J.H. \& McCoy E.D. 2007: The risk of classical biological control in Florida. Biol. Control 41: 151-174.

Frazer B.D. 1988: Coccinellidae. In Minks A.K. \& Harrewijn P. (eds): Aphids, their Biology, Natural Enemies and Control. Vol. 2B. Elsevier, Amsterdam, pp. 231-248.

Frazer B.D. \& Raworth D.A. 1985: Sampling for adult coccinellids and their numerical response to strawberry aphids (Coleoptera: Coccinellidae; Homoptera: Aphididae). Can. Entomol. 117: 153-161.
Fye R.E. \& CARRanza R.L. 1972: Movement of insect predators from grain sorghum to cotton. Environ. Entomol. 1: 790-791.

Galvan T.L., Косh R.L. \& Hutchison W.D. 2005: Toxicity of commonly used insecticides in sweet corn and soybean to multicolored Asian lady beetle (Coleoptera: Coccinellidae). $J$. Econ. Entomol. 98: 780-789.

GARDINER M.M. \& LANDIS D.A. 2007: Impact of intraguild predation by adult Harmonia axyridis (Coleoptera: Coccinellidae) on Aphis glycines (Hemiptera: Aphididae) biological control in cage studies. Biol. Control 40: 386-395.

Gruppe A. \& Roemer P. 1988: The lupin aphid (Macrosiphum albifrons Essig) (Hom., Aphididae) in West Germany: its occurrence, host plants and natural enemies. Z. Angew. Entomol. 106: 135-143.

HAGEN K.S. 1962: Biology and ecology of predaceous Coccinellidae. Annu. Rev. Entomol. 7: 289-326.

HAGEN K.S. 1974: The significance of predaceous Coccinellidae in biological and integrated control of insects. Entomophaga (Mém. H.S.) 7: 25-44.

HARMon J.P., Stephen E. \& Losey J. 2007: The decline of native coccinellids (Coleoptera: Coccinellidae) in the United States and Canada. J. Insect Conserv. 11: 85-94.

HemptinNe J.-L. 1989: Ecophysiologie d'Adalia bipunctata (L.) (Coleoptera: Coccinellidae). Thèse de doctorat, Université Libre de Bruxelles, 156 pp.

Hemptinne J.-L., Dixon A.F.G. \& Coffin J. 1992: Attack strategy of ladybird beetles (Coccinellidae): factors shaping their numerical response. Oecologia 90: 238-245.

Hemptinne J.-L., Lognay G., Gauthier C. \& Dixon A.F.G. 2000: Role of surface chemical signals in egg cannibalism and intraguild predation in ladybirds (Coleoptera: Coccinellidae). Chemoecology 10: 123-128.

Hemptinne J.-L., Lognay G., Doumbia M. \& Dixon A.F.G. 2001: Chemical nature and persistence of the oviposition deterring pheromone in the tracks of the larvae of the two spot ladybird, Adalia bipunctata (Coleoptera: Coccinellidae). Chemoecology 11: 43-47.

HiRose Y. 2006: Biological control of aphids and coccids: a comparative analysis. Pop. Ecol. 48: 307-315.

HoDeK I. 1956: [The influence of Aphis sambuci as prey of the ladybird beetle Coccinella septempunctata.] Acta Soc. Zool. Bohemoslov. 20: 62-74 [in Czech, English abstr.].

HodEK I. 1960: [Hibernation-bionomics in Coccinellidae.] Čas. Čs. Spol. Entomol. 57: 1-20 [in Czech, English abstr.].

Hodek I. 1962: Experimental influencing of the imaginal diapause in Coccinella septempunctata (Col., Coccinellidae). Čas. Cs. Spol. Entomol. 59: 297-313.

HoDEK I. 1966: Voltinism and diapause in aphidophagous insects (Review). In Hodek I. (ed.): Ecology of Aphidophagous Insects. W. Junk, The Hague and Academia, Prague, pp. $97-102$.

Hodek I. 1973: Biology of Coccinellidae. Academia, Prague and W. Junk, The Hague, 260 pp.

Hodek I. 1996a: Dormancy. In Hodek I. \& Honěk A. (eds): Ecology of Coccinellidae. Kluwer Academic, Dordrecht, pp. 239-318.

Hodek I. 1996b: Food relationships. In Hodek I. \& Honěk A. (eds): Ecology of Coccinellidae. Kluwer Academic, Dordrecht, pp. 143-238.

Hodek I. \& Ceryngier P. 2000: Sexual activity in Coccinellidae (Coleoptera): a review. Eur. J. Entomol. 97: 449-456.

Hodek I. \& HonĚK A. (eds) 1996a: Ecology of Coccinellidae. Kluwer Academic, Dordrecht, $464 \mathrm{pp}$.

HodeK I. \& HonĚK A. 1996b: Effectiveness and utilization. In Hodek I. \& Honěk A. (eds): Ecology of Coccinellidae. Kluwer Academic, Dordrecht, pp. 351-389. 
Hodek I. \& Landa V. 1971: Anatomical and histological changes during dormancy in two Coccinellidae. Entomophaga 16: 239-251.

Hodek I., IPerTI G. \& Rolley F. 1977: Activation of hibernating Coccinella septempunctata (Coleoptera) and Perilitus coccinellae (Hymenoptera) and photoperiodic response after diapause. Entomol. Exp. Appl. 21: 275-286.

Hodek I., RŮžıčKa Z. \& Hodková M. 1978: Pollinivorie et aphidiphagie chez Coleomegilla maculata (De Geer). Ann. Zool. Ecol. Anim. 10: 453-459.

Hodek I., Okuda T. \& Hodková M. 1984: Reverse photoperiodic responses in two subspecies of Coccinella septempunctata (Col., Coccinellidae). Zool. Jb. Syst. 111: 439-448.

Holloway G.J., de Jong P.W., Brakefield P.M. \& de Vos H. 1991: Chemical defence in ladybird beetles (Coccinellidae). I. Distribution of coccinelline and individual variation in defence in 7-spot ladybird, Coccinella septempunctata. Chemoecology 2: 7-14.

HoNĚK A. 1989: Overwintering and annual changes of abundance of Coccinella septempunctata in Czechoslovakia (Coleoptera, Coccinellidae). Acta Entomol. Bohemoslov. 86: 179-192.

HoNĚK A. \& HoDEK I. 1996: Distribution in habitats. In Hodek I. \& Honěk A. (eds): Ecology of Coccinellidae. Kluwer Academic, Dordrecht, pp. 95-141.

HonĚK A. \& MARTinKovÁ Z. 2005: Long term changes in abundance of Coccinella septempunctata (Coleoptera: Coccinellidae) in the Czech Republic. Eur. J. Entomol. 102: 443-448.

IPERTI G. 1999: Biodiversity of predaceous Coccinellidae in relation to bio-indication and economic importance. Agr. Ecosyst. Env. 74: 323-342.

Ives A.R., Kareiva P. \& Perry R. 1993: Response of a predator to variation in prey density at 3 hierarchical scales - lady beetles feeding on aphids. Ecology 74: 1929-1938.

Kajita Y., Takano F., Yasuda H. \& Evans E.W. 2006: Interactions between introduced and native predatory ladybirds: factors influencing the success of species introductions. Ecol. Entomol. 31: 58-67.

Kareiva P. 1990: Population dynamics in spatially complex environments - theory and data. Phil. Trans. R. Soc. London (B) 330: 175-190.

Katsoyannos P., Kontodimas D.C. \& Stathas G. 2005: Summer diapause and winter quiescence of Hippodamia (Semiadalia) undecimnotata (Coleoptera: Coccinellidae) in central Greece. Eur. J. Entomol. 102: 453-457.

Kindlmann P. \& Dixon A.F.G. 1993: Optimal foraging in ladybird beetles (Coleoptera: Coccinellidae) and its consequences for their use in biological control. Eur. J. Entomol. 90: 443-450.

KindlmanN P. \& Dixon A.F.G. 1999: Strategies of aphidophagous predators: lessons for modelling insect predator-prey dynamics. J. Appl. Entomol. 123: 397-399.

KindLMANN P. \& HoudKovÁ H. 2006: Intraguild predation: fiction or reality? Popul. Ecol. 48: 317-322.

KLAUSNITZER B. 1989: Marienkaferansammlungen am Ostseestrand. Entomol. Nachr. Ber. 33: 189-194.

Косн R.L. 2003: The multicolored Asian lady beetle, Harmonia axyridis: A review of its biology, uses in biological control, and non-target impacts. J. Insect Sci. 3.32: 1-16.

Krafsur E.S., ObrycKi J.J. \& Harwood J.D. 2005: Comparative genetic studies of native and introduced Coccinellidae in North America. Eur. J. Entomol. 102: 469-474.

Kriz J.C., Danielson S.D., Brandle J.R., Blankenship E.E. \& Henebry G.M. 2006: Effect of aphid (Homoptera) abundance and surrounding vegetation on the encounter rate of Coccinel- lidae (Coleoptera), Chrysopidae (Neuroptera), and Nabidae (Hemiptera) in alfalfa. J. Entomol. Sci. 4: 211-220.

Landis D.A., Wratten S.D. \& GuRR G.M. 2000: Habitat management to conserve natural enemies of arthropod pests in agriculture. Annu. Rev. Entomol. 45: 175-201.

LEwontin R.C. 1965: Selection for colonizing ability. In Bakker H.G. \& Stebbins G.L. (eds): The Genetics of Colonizing Species, Acad. Press, New York, pp. 77-94.

Louda S.M., Pemberton R.W., Johnson M.T. \& Follett P.A. 2003: Non-target effects - the Achilles' heel of biological control? Retrospective analyses to reduce risks associated with biocontrol introductions. Annu. Rev. Entomol. 48: 365-396.

Lucas E., Coderre D. \& Vincent C. 1997: Voracity and feeding preferences of two aphidophagous coccinellids on Aphis citricola and Tetranychus urticae. Entomol. Exp. Appl. 85: 151-159.

Lucas E., Vincent C., Labrie G., Chouinard G., Fournier F., Pelletier F., Bostanian N.J., Coderre D., Mignault M.-P. \& LAfontaine P. 2007: The multicolored Asian ladybeetle Harmonia axyridis (Coleoptera: Coccinellidae) in Quebec agroecosystems ten years after its arrival. Eur. J. Entomol. 104: 737-743.

Lundgren J.G., Razzak A.A. \& Wiedenmann R.N. 2004: Population responses and food consumption by predators Coleomegilla maculata and Harmonia axyridis (Coleoptera: Coccinellidae) during anthesis in an Illinois cornfield. Environ. Entomol. 33: 958-963.

Mack R.N., Simberloff D., Lonsdale W.M., Evans H., Clout M. \& BAzzAZ F.A. 2000: Biotic invasions: causes, epidemiology, global consequencies, and control. Ecol. Appl. 10: 689-710.

Majerus M.E.N. 1994: Ladybirds. Harper Collins, London, 367 pp.

Maredia K.M., Gage S.H., Landis D.A. \& Scriber J.M. 1992: Habitat use patterns by the seven-spotted lady beetle in a diverse agricultural landscape. Biol. Control 2: 159-165.

Michaud J.P. 2002: Invasion of the Florida citrus ecosystem by Harmonia axyridis (Coleoptera: Coccinellidae) and asymmetric competition with a native ladybeetle, Cycloneda sanguinea. Environ. Entomol. 31: 824-835.

Michaud J.P. 2004: Natural mortality of Asian citrus psyllid, Diaphorina citri (Homoptera: Psyllidae) in central Florida. Biol. Control 29: 260-269.

Michaud J.P. \& GRANT A.K. 2003: Intraguild predation among ladybeetles: Do the larval spines of the Chilocorinae (Coleoptera: Coccinellidae) serve a defensive function? Bull. Entomol. Res. 93: 499-505.

Michaud J.P. \& Jyоті J.L. 2007: Repellency of conspecific and heterospecific larval residues to Hippodamia convergens (Coleoptera: Coccinellidae) ovipositing on sorghum plants. Eur. J. Entomol. 104: 399-405.

Michaud J.P. \& QURESHI J.A. 2005: Induction of reproductive diapause in Hippodamia convergens (Coleoptera: Coccinellidae) hinges on prey quality and availability. Eur. J. Entomol. 102: 483-487.

Michaud J.P. \& QuREShi J.A. 2006: Reproductive diapause in Hippodamia convergens (Coleoptera: Coccinellidae) and its life history consequences. Biol. Control 39: 193-200.

Mignault M.P., Roy M. \& Brodeur J. 2006: Soybean aphid predators in Quebec and the suitability of Aphis glycines as prey for three Coccinellidae. BioControl 51: 89-106.

Mills N.J. 1979: Adalia bipunctata as a Generalist Predator of Aphids. PhD Thesis, University of East Anglia, Norwich.

Mills N.J. 1981: Essential and alternative foods for some British Coccinellidae. Entomol. Gaz. 32: 197-202. 
Mondor E.B. \& Roitberg B.D. 2000: Has the attraction of predatory coccinellids to cornicle droplets constrained aphid alarm signaling behavior? J. Insect Behav. 13: 321-329.

Nakashima Y., Birkett M.A., Pye B.J. \& Powell W. 2006: Chemically mediated intraguild predator avoidance by aphid parasitoids: Interspecific variability in sensitivity to semiochemical trails of ladybird predators. J. Chem. Ecol. 32: 1989-1998.

Nedvěd O., Ceryngier P., Hodková M. \& Hodek I. 2001: Flight potential and oxygen uptake during early dormancy in Coccinella septempunctata. Entomol. Exp. Appl. 99: 371-380.

NiIJIMA K., Matsuka M. \& OKada I. 1986: Artificial diets for an aphidophagous coccinellid, Harmonia axyridis, and its nutrition. In Hodek I. (ed.): Ecology of Aphidophaga. Academia, Prague and W. Junk, Dordrecht, pp. 37-50.

Obrycki J.J. \& Kring TJ. 1998: Predaceous Coccinellidae in biological control. Annu. Rev. Entomol. 43: 295-321.

OBRYCKI J.J. \& TAUBER M.J. 1981: Phenology of three coccinellid species: thermal requirements for development. Ann. Entomol. Soc. Am. 74: 31-36.

ObRYCKi J.J., GILES K.L. \& ORMORD A.M. 1998: Interactions between an introduced and indigenous coccinellid species at different prey densities. Oecologia 117: 279-285.

Ohashi K., Kawauchi S.E. \& Sakuratani Y. 2003: Geographic and annual variation of summer-diapause expression in the ladybird beetle, Coccinella septempunctata (Coleoptera: Coccinellidae), in Japan. Appl. Entomol. Zool. 38: 187-196.

Ohashi K., Sakuratani Y., Osawa N., Yano S. \& Takafuji A. 2005: Thermal microhabitat use by the ladybird beetle, Coccinella septempunctata, and its life cycle consequences. Environ. Entomol. 34: 432-439.

OKuda T. \& HodeK I. 1983: Response to constant photoperiods in Coccinella septempunctata brucki populations from central Japan. Acta Entomol. Bohemoslov. 80: 74-75.

Osawa N. 2000: Population field studies on the aphidophagous ladybird beetle Harmonia axyridis (Coleoptera: Coccinellidae): resource tracking and population characteristics. Popul. Ecol. 42: 115-127.

Osawa N. 2005: The effect of prey availability on ovarian development and oosorption in the ladybird beetle Harmonia axyridis (Coleoptera: Coccinellidae). Eur. J. Entomol. 102: 503-511.

Patt J.M., Hamilton G.C. \& Lashomb J.H. 1997: Impact of strip-insectary intercropping with flowers on conservation biological control of the Colorado potato beetle. Adv. Hort. Sci. 11: 175-181.

PERRIN R.M. 1976: The population dynamics of the stinging nettle aphid, Microlophium carnosum. Ecol. Entomol. 1: $31-40$.

Phoofolo M.W. \& OBRYcki J.J. 1995: Comparative life-history studies of Nearctic and Palearctic populations of Coccinella septempunctata (Coleoptera: Coccinellidae). Environ. Entomol. 24: 581-587.

Phoofolo M.W. \& Obrycki J.J. 2000: Demographic analysis of reproduction in Nearctic and Palearctic populations of Coccinella septempunctata and Propylea quatuordecimpunctata. BioControl 45: 25-43.

Reitz S.R. \& Trumble J.T. 2002: Competitive displacement among insects and arachnids. Annu. Rev. Entomol. 47: 435-465.

Remaudiere G., Latge J.P. \& Michel M.F. 1980: Evolution des populations de pucerons du littoral de Basse-Normandie. Acta Oecol. - Oecol. Appl. 1: 341-355.

Ricci C., Ponti L. \& Pires A. 2005: Migratory flight and prediapause feeding of Coccinella septempunctata (Coleoptera) adults in agricultural and mountain ecosystems of Central Italy. Eur. J. Entomol. 102: 531-538.

RiCE M.E. \& WILDE G.E. 1988: Experimental evaluation of predators and parasitoids in suppressing greenbugs (Homoptera: Aphididae) in sorghum and wheat. Environ. Entomol. 17: 836-841.

RŮŽIČKA Z. 1994: Oviposition-deterring pheromone in Chrysopa oculata (Neuroptera: Chrysopidae). Eur. J. Entomol. 91: 361-370.

RƯŽIČKA Z. 1997: Recognition of oviposition-deterring allomones by aphidophagous predators (Neuroptera: Chrysopidae, Coleoptera: Coccinellidae). Eur. J. Entomol. 94: 431-434.

RŮŽIČKA Z. 2001: Oviposition responses of aphidophagous coccinellids to tracks of ladybird (Coleoptera: Coccinellidae) and lacewing (Neuroptera: Chrysopidae) larvae. Eur. J. Entomol. 98: $183-188$.

RŮŽIČKA Z. 2002: Persistence of deterrent larval tracks in Coccinella septempunctata, Cycloneda limbifer and Semiadalia undecimnotata (Coleoptera: Coccinellidae). Eur. J. Entomol. 99: 471-475.

SAKURAi H., Mori Y. \& Takeda H. 1981: Studies on the diapause of Coccinella septempunctata brucki. I. Physiological changes related to aestivation and hibernation. Res. Bull. Fac. Agr. Gifu Univ. 45: 9-15 [in Japanese, English abstr.].

Sakuratani Y., Matsumoto Y., Oka M., Kubo T., Fuji A. \& Votani M. 2000: Life history of Adalia bipunctata (Coleoptera, Coccinellidae) in Japan. Eur. J. Entomol. 97: 555-558.

Sato S., Dixon A.F.G. \& YAsuda H. 2003: Effect of emigration on cannibalism and intraguild predation in aphidophagous ladybirds. Ecol. Entomol. 28: 628-633.

Sato S., Yasuda H. \& Evans E.W. 2005: Dropping behaviour of larvae of aphidophagous ladybirds and its effect on incidence of intraguild predation: interactions between the intraguild prey, Adalia bipunctata and Coccinella septempunctata, and the intraguild predator, Harmonia axyridis. Ecol. Entomol. 30: 220-224.

Sengonca C. \& Liu B. 1994: Responses of the different instar predator, Coccinella septempunctata L. (Coleoptera: Coccinellidae), to the kairomones produced by the prey and nonprey insects as well as the predator itself. Z. PflKrankh. PflSchutz 101: 173-177.

SlogGett J.J. 2005: Are we studying too few taxa? Insights from aphidophagous ladybird beetles (Coleoptera: Coccinellidae). Eur. J. Entomol. 102: 391-398.

Sмітн B.C. 1960: A technique for rearing coccinellid beetles on dry foods, and influence of various pollens on the development of Coleomegilla maculata lengi Timb. (Coleoptera: Coccinellidae). Can. J. Zool. 38: 1047-1049.

SMith R.F. \& Hagen K.S. 1966: Natural regulation of alfalfa aphids in California. In Hodek I. (ed.): Ecology of Aphidophagous Insects. Academia, Prague and W. Junk, Hague, pp. 297-315.

Snyder W.E., Clevenger G.M. \& Eigenbrode S.D. 2004a: Intraguild predation and successful invasion by introduced ladybird beetles. Oecologia 140: 559-565.

Snyder W.E., Ballard S.N., Yang S., Clevengerer G.M., Miller T.D., Ahn J.J., Hatten T.D. \& Berryman A.A. 2004b: Complementary biocontrol of aphids by the ladybird beetle Harmonia axyridis and the parasitoid Aphelinus asychis on greenhouse roses. Biol. Control 30: 229-235.

SNYder W.E. \& Evans E.W. 2006: Ecological effects of invasive arthropod generalist predators. Annu. Rev. Ecol. Evol. Syst. 37: 95-122. 
Snyder W.E., Snyder G.B., Finke D.L. \& Straub C.S. 2006 Predator biodiversity strengthens herbivore suppression. Ecol. Let. 9: 789-796.

Stern V.M., Smith R.F., van den Bosch R. \& Hagen K.S. 1959: Integration of chemical and biological control of the spotted alfalfa aphid. Hilgardia 29: 81-154.

Straub C.S. \& SNyder W.E. 2006: Species identity dominates the relationship between predator biodiversity and herbivore suppression. Ecology 87: 277-282.

Symondson W.O.C., Sunderland K.D. \& Greenstone M.H. 2002: Can generalist predators be effective biocontrol agents? Annu. Rev. Entomol. 47: 561-594.

THORPE M.A. 1930: The biology, post-embryonic development, and economic importance of Cryptochaetum iceryae (Diptera, Agromyzidae) parasitic on Icerya purchasi (Coccidae, Monophlebini). Proc. Zool. Soc. London 60: 929-971.

TURNOCK W.J. \& WISE I.L. 2004: Density and survival of lady beetles (Coccinellidae) in overwintering sites in Manitoba. Can. Field Nat. 118: 309-317.

UnGer K. \& Mueller H.J. 1954: Uber die Wirkung gelandeklimatisch unterschiedlicher Standorte auf den Blattlausbefallsflug. Der Zuchter 24: 341 .

VAN DER Werf W., Evans E.W. \& Powell J. 2000: Measuring and modelling the dispersal of Coccinella septempunctata (Coleoptera: Coccinellidae) in alfalfa fields. Eur. J. Entomol. 97: 487-493.

van Lenteren J.C., Bale J., Bigler F., Hokkanen H.M.T. \& LoOMAns A.J.M. 2006: Assessing risks of releasing exotic biological control agents of arthropod pests. Annu. Rev. Entomol. 51: 609-634. van Risn P.C.J., Burgio G. \& Thomas M.B. 2006: Impact of intraspecific and intraguild predation on predator invasion and coexistence: Can exotic ladybeetles displace native species? In Hoddle M.S. (ed.): Second International Symposium on Biological Control of Arthropods. USDA Forest Service Publication, pp. 38-47.

VolKL W. \& Vohland K. 1996: Wax covers in larvae of two Scymnus species: do they enhance coccinellid larval survival? Oecologia 107: 498-503.

Wheeler A.G., JR. \& HoebeKe E.R. 1995: Coccinella novemnotata in northeastern North America: historical occurrence and current status (Coleoptera: Coccinellidae). Proc. Entomol. Soc. Wash. 97: 701-716.

Wratten S.D. 1974: Aggregation in the birch aphid, Euceraphis punctipennis, in relation to food quality. J. Anim. Ecol. 43: 191-198.

YANO E. 2006: Ecological considerations for biological control of aphids in protected culture. Popul. Ecol. 48: 333-339.

Yasuda H. \& OHNuma N. 1999: Effect of cannibalism and predation on the larval performance of two ladybird beetles. Entomol. Exp. Appl. 93: 63-67.

Zaslavsky V.A. \& Vaghina N.P. 1996: Joint and separate effects of photoperiodic and alimentary induction of diapause in Coccinella septempunctata (Coleoptera, Coccinellidae). Zool. Zh. 75: 1474-1482.

ZhU J.W. \& PARK K.C. 2005: Methyl salicylate, a soybean aphid-induced plant volatile attractive to the predator Coccinella septempunctata. J. Anim. Ecol. 31: 1733-1746.

Received September 5, 2007; revised and accepted November 2, 2007 